\title{
Homo oeconomicus versus homo personalis. Człowiek pomiędzy ekonomią a etyka
}

DOI: http://dx.doi.org/10.12775/RF.2014.018

\section{Wstęp}

Już w starożytności pojawiały się pierwsze koncepcje ujmujące wspólnotowości życia ludzkiego. Platońskie Państwo ${ }^{1}$ pojmowane było jako swoista kolektywna wspólnota, Arystoteles zaś widział w człowieku

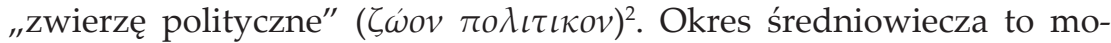
narchia feudalna, a później stanowa, w których uprzywilejowane jednostki sprawują władzę nad całą resztą społeczeństwa3.

W XVII wieku wpływową teorię dotyczącą wzajemnych stosunków międzyludzkich przedstawił Thomas Hobbes. Wskazując na namiętności „szarpiące" ludzką naturę, stwierdził, że człowiek jest zasadniczo egoista, którego celem jest wyłącznie zaspakajanie swych potrzeb. Dążność do dostatku, władzy i zaszczytów jest powszechna, aczkolwiek nie zawsze w pełni osiągalna, albowiem na drodze stoją inni ludzie. Stąd też pojawia się słynna Hobbesowska koncepcja wojny wszystkich z wszystkimi (bellum omnia contra omnes). W tym starciu nie obowiązują żadne zasady prawne czy moralne, ostateczną decyzję zaś podejmuje państwo $0^{4}$.

Mniej więcej w 100 lat później Adam Smith przedstawił zgoła inną wizję człowieka i jego relacji względem społeczeństwa i państwa. Nie-

1 Zob. Platon, Państwo, przeł. W. Witwicki, Wydawnictwo Antyk, Kęty 2003.

2 Zob. Arystoteles, Polityka, przeł. i oprac. L. Piotrowicz, Zakład im. Ossolińskich, Wrocław 1953.

3 Zob. J. Baszkiewicz, Powszechna historia ustrojów państwowych, Arche, Gdańsk 1998, s. 79-176.

4 Zob. T. Hobbes, Lewiatan, czyli materia, forma i władza państwa kościelnego i świeckiego, przeł. Cz. Znamierowski, PWN, Warszawa 1954. 
którzy myśliciele uważaja że te dwie konkurencyjne wizje do dziś stanowią filozoficzną podstawę różnego rozumienia miejsca i wzajemnych relacji poszczególnych jednostek ludzkich względem siebie i państwa ${ }^{5}$. Hobbes postrzega bowiem państwo jako antidotum na anarchię szerzącą się w stanie natury pomiędzy ludźmi. Powstrzymuje ono wzajemną rywalizację oraz nieujarzmione tendencje do zaspokajania swych potrzeb. Dla Smitha sytuacja ta wyglądała wręcz odwrotnie. Nie widział w tych dążnościach negatywnych skłonności, albowiem pojmował je raczej jako podwalinę pod możliwość daleko posuniętego rozwoju gospodarczego.

\section{Filozoficzne zręby homo oeconomicus}

W swoich rozważaniach Smith twierdził, że ludzie wprawdzie rywalizują między soba, czynią to jednak w trosce o swoje własne interesy, a żeby je zrealizować, koniecznością jest wejście z innymi w przeróżne interakcje, które na polu gospodarczym przyjmują wymiar wymiany różnorakich towarów i usług. Ostatecznie więc pomimo istniejącej sporej konkurencji, chęć osiągnięcia własnego dobra sprawia, że następuje swoista wzajemna skłonność dogadania się ponad podziałami. Sytuacja taka prowadzi do małego paradoksu. Otóż, okazuje się, że ludzie w pogoni za realizacją własnych egoistycznych dążeń, w obszarze działań rynkowych, skłonni są realizować także interesy obcych ludzi, o ile mają one korzystny wpływ na osiągnięcie własnych celów. Okazuje się więc, że najlepszą ochroną własnych praw jest przestrzeń wolnego ryn$\mathrm{ku}$, gdzie każdy osiąga tyle, ile potrafi utargować u innych, a zarazem na ile potrafi zgrać swoje poczynania z tendencjami uczestników wzajemnej wymiany rynkowej. W konsekwencji państwo nie tylko nie jest tu konieczne, ale nawet może być postrzegane jako zbędne, zwłaszcza w kontekście ewentualnego „mieszania się” w realizację partykularnych interesów poszczególnych obywateli. To nie państwo, a rynek jest ostateczną instancją regulującą prawa i aktywność poszczególnych jego podmiotów.

Dla ekonomicznej doktryny Smitha punktem wyjścia była filozoficzna idea gospodarczego harmonizowania ludzkiej natury utworzonej przez Opatrzność 6 . Zresztą jego poglądy w znacznej mierze wyrastają z filozofii Johna Locke'a, określonej przez znawców myśli politycznej jako liberalna. O ile jednak Locke podkreślał w swych rozważaniach w szczególności perspektywę polityczno-ustrojowa, o tyle Smith pod-

5 Zob. W. Morawski, Socjologia ekonomiczna. Problemy, teoria, empiria, Wydawnictwo Naukowe PWN, Warszawa 2001, s. 120-123.

6 Zob. H. Izdebski, Historia myśli politycznej i prawnej, C. H. Beck, Warszawa 2001, s. 139 . 
kreślał raczej wymiar ekonomiczno-liberalny społeczeństwa i państwa. W tym kontekście także zaczyna się pojawiać słynna koncepcja homo oeconomicus, opracowana wprawdzie wiele lat później, jednak właśnie u tego myśliciela mająca swe korzenie.

W późniejszym czasie w pewnym aspekcie nawiązywał do tych rozważań John Stuart Mill. W jego twórczości można odnaleźć myśl sugerująca, że ekonomia jest przede wszystkim nauką o zachowaniach egoistycznych, co jest motywowane dbałością o interes własny. Wynikało to przede wszystkim z jego filozofii utylitarystycznej, w której działanie ludzkie motywowane było osiągniętym szczęściem, będącym jedynym dobrem i zarazem celem, do którego dążą wszyscy ludzie 7 . Nieważne przy tym są same różnice ilościowe czy jakościowe w zaznawanych przyjemnościach. Ważniejsza staje się tu zasada użyteczności, której etyczność musi być „,ugruntowana na niezmiennych interesach człowieka jako istoty postępowej"8.

Pojawia się jednak problem ze zrozumieniem owych interesów człowieka, gdyż Mill nie zaprezentował jednolitej i pełnej wykładni natury człowieka. Można więc jedynie z różnych jego pism wnioskować, że głównym jej elementem jest indywidualność każdej jednostki ludzkiej, którą rozumiał jako rozwój każdego człowieka9 . Zasada taka odgrywa $\mathrm{u}$ Milla istotną rolę $\mathrm{w}$ koncepcji jego społeczno-politycznej wolności. W tym kontekście doskonale sprawdza się znane hasło, że granicą własnej wolności jest wolność drugiego człowieka ${ }^{10}$. Wskazywał on więc, że zgodnie z zasadą użyteczności każdy człowiek - według własnych osądów i woli - powinien się swobodnie rozwijać, pod warunkiem że nie przeszkadza to w swobodzie rozwoju innej jednostki. „Każdy jest odpowiedzialny przed społeczeństwem jedynie za tę część swojego postępowania, która dotyczy innych. W tej części, która dotyczy wyłącznie jego samego, jest absolutnie niezależny; ma suwerenną władzę nad soba, nad swoim ciałem i umysłem"11. W takich słowach wyraźnie objawia się stanowisko wskazujące na indywidualne prawo każdego człowieka do osobistej wolności, którego podstawą jest zasada użyteczności. Jedynym ogranicznikiem dla tak pojmowanej wolności jest ewentualna możliwość wyrządzenia innym krzywdy.

Jak jednak określić tę krzywdę? Jaka jest granica wolności między jednostką a społeczeństwem? Sam Mill, próbując rozwiązać ten dylemat,

7 Zob. J. S. Mill, Utylitaryzm. O wolności, przeł. M. Ossowska, A. Kurlandzka, PWN, Warszawa 1959, s. 13.

8 Idem, O wolności, s. 131.

9 Zob. ibidem, s. 208.

10 Mill zasadę tę zawarł w słowach: „Wolność jednostki musi być ograniczona do tego stopnia, by nie sprawiała przykrości innym". Ibidem, s. 197.

11 Ibidem, s. 129. 
powołuje się na stwierdzenie Wilhelma von Humboldta wskazując, że celem człowieka ,jest najwyższy i najbardziej harmonijny rozwój jego władz złączonych w jedną logiczną całość"12. Sugeruje więc, że szczęście społeczeństwa będzie wtedy pełne, kiedy każdy człowiek harmonijnie będzie się rozwijał i zachowa niespaczoną osobowość. Ostatecznie więc skłania się ku rozwiązaniu, że dobro ogółu wymaga, aby każdy posiadł indywidualnie tyle wolności, ile tylko może. Społeczeństwo absolutnie nie powinno zatem ingerować w zakres prywatnej wolności (ona sama staje się niejako res sacra), poza przypadkami, gdy ewentualna samowola mogłaby wyrządzić wyraźną szkodę innym.

Z tych antropologiczno-etycznych dywagacji wyłania się - być może w sposób niezgrabny, ale za to stanowczy - obraz człowieka, który przesiąknięty jest głównym celem swojej egzystencji. Jest nim zachowanie własnej wolności, a ta realizowana jest przez skrajnie zindywidualizowane działania, nakierowane na osiągnięcie osobistego dobra, którym jest szczęście. Wprawdzie w filozofii Milla pojawiają się, raz za razem, odniesienia do szerszego kontekstu społecznego, w którym wskazuje na ogólnoludzką tendencję do zaspokojenia przyjemności dających szczęście, także przez realizację swobodnego wyboru dróg realizujących wolność osobista, jednak każdorazowo ostatecznym fundamentem dla takiego działania jest zindywidualizowane dobro danego człowieka. Można rzec, że to właśnie troska o własny byt, własną wolność, własne dobra, daje każdej jednostce ludzkiej poczucie osobistego szczęścia, opierającego się ostatecznie na egoistycznym umiłowaniu samego siebie.

W ten oto sposób stopniowo wyłania się koncepcja człowieka, która po dzień dzisiejszy odgrywa istotną rolę - jest nią homo oeconomicus. Jaki jest ów sławetny twór i jakie są jego charakterystyczne cechy? Aby odpowiedzieć na to pytanie, trzeba zebrać wypowiedzi różnych myślicieli, działających na pograniczu filozofii, socjologii, ekonomii, a nawet psychologii. Przywołując wpierw Smitha, trzeba zauważyć, że jego koncepcja człowieka pojawia się w kontekście analizy mechanizmów rynkowych. Wskazana w jego pismach teoria samorzutnego rozwoju ukonstytuowana została na fundamencie indywidualizmu, dzięki któremu działania poszczególnych jednostek, czasem nawet przy nikłej ich świadomości, przyczyniają się do dobra ogółu przez spontaniczne tworzenie się instytucji. Człowiek uwikłany w działania ekonomiczne pojmowany jest od strony antropologicznej jako istota skłonna do wymiany, handlu i zamieniania jednej rzeczy na drugą. Posiada swą wolność, którą w bezapelacyjny sposób wykorzystuje do osiągnięcia jak największych korzyści własnych. Zarazem potrzebuje społecznego odniesienia, potrzebuje

12 Ibidem, s. 235. 
innych ludzi do realizacji swych zamierzeń, w wyniku których następuje akt wzajemnej wymiany i współpracy ${ }^{13}$.

Krytycznie modeluje tę wizję Mill. Sugeruje bowiem, że ekonomia jako nauka społeczna ${ }^{14}$, kreuje w swym łonie abstrakcyjną i arbitralną zarazem koncepcję człowieka. Jest to jednostka ludzka, która stara się uzyskać jak największą liczbę rzeczy niezbędnych w swoim życiu, a zarazem przynoszących wygodę i luksus. Przy czym stan taki jednostka ta chce uzyskać tak małą ilością pracy, trudu i wyrzeczeń, jak tylko pozwala na to stan jej wiedzy. W efekcie tego może dojść do zdumiewającego aliansu. O ile bowiem pracownik pojmie, że w wyniku jakichś działań będzie mógł osiągnąć większą płacę, a kapitalista (czy właściciel ziemski) większy zysk, o tyle dochodzi pomiędzy nimi do porozumienia, w celu uzyskania pożądanych dóbr.

Rzeczywistość ekonomiczna oparta wtedy jest na zysku i wydajności, produkcji oraz wzajemnej wymianie, jak też dobrach materialnych i ich wartości użytkowej. Wynika z tego, że

klasyczne prawa ekonomii politycznej uwzględniają w człowieku wyłącznie postawę ekonomiczną. Można ją uzasadnić tylko przy założeniu, że człowiek zawsze postępuje racjonalnie, że oblicza wszystko według jakieś skali wartości, że podporządkowuje stale chwilę bieżącą korzyściom przyszłym $[\ldots]^{15}$.

Ponadto, tendencje takie wiodą do skrajnego redukowania złożonych stosunków interpersonalnych. W efekcie nabierają one charakteru „bezosobowych kontaktów” umożliwiających zawarcie „biznesowych projektów", mających na celu realizację indywidualnych tendencji każdej ze stron biorących udział w takiej transakcji. Takie bezosobowe relacje „wzbudzić mogą co najwyżej gorącą chęć zrobienia dobrego interesu, same jednak osoby pozostają emocjonalnie obojętne"16. Można wręcz odnieść wrażenie, że wzajemne kontakty osób biorących udział w negocjacjach nad realizacją poszczególnych interesów dokonują się na zasadzie komunikowania się dwu maszyn (komputerów) spełniających wcześniej zaprogramowane funkcje.

W takim kontekście homo oeconomicus nabiera specyficznego znaczenia. Dlatego też w swych pracach ekonomicznych Mill ujmował go

13 A. Smith, Teoria uczuć moralnych, przeł., wstępem i przypisami opatrzyła D. Petsch, PWN, Warszawa 1989, s. 349 i n.

14 J. S. Mill, One the Definition of Political Economy and on the Method of Investigation Proper to it, w: Essays on Economics Society, Collected Works, t. 4, Toronto 1967, s. 320-321.

15 S. Ossowski, Z zagadnień psychologii społecznej, Wydawnictwo Naukowe PWN, Warszawa 2000, s. 126.

16 Z. Bauman, Socjologia, przeł. J. Łoziński, Zysk i S-ka, Poznań 1996, s. 101. 
w sferze czystej abstrakcji. Nie jest to żaden realny byt, a co najwyżej „przydatna do pewnych celów fikcja poznawcza"17. Od samego niemal początku taka postać człowieka nabiera wymiaru wyłącznie funkcjonalistycznego. Nie pokazuje się tu pełnej struktury antropologicznej (nawet w sposób szczątkowy), a raczej popełnia błąd genetyczny, w którym całą ludzką bytowość sprowadza się wyłącznie do aspektów ekonomicznych. Pojawia się także błąd naturalistyczny ${ }^{18}$, w którym w specyficznie indywidualistycznym autyzmie, ,jednowymiarowy" człowiek wydaje się pozbawiony wszelkich uczuć ${ }^{19}$. Stąd też Émile Durkheim utyskiwał, że w takich okolicznościach głównym zadaniem społeczeństwa jest dbałość o niezależność i dostatek materialny poszczególnych jednostek ludzkich ${ }^{20}$. Mocno krytykowano także doktrynę Smitha, zarzucając mu zbyt daleko posunięty uniwersalizm, jak też absolutyzm ${ }^{21}$.

\section{Homo oeconomicus i jego etyka}

Jak to zostało już wcześniej zauważone, przestrzeń etyczna, w jakiej porusza się homo oeconomicus, wyraża się przede wszystkim w utylitaryzmie. W wersji prezentowanej przez Jeremy'ego Benthama i Milla system ten przyjmuje wymiar maksymalizowania przyjemności działającego podmiotu wobec maksymalnej liczby ludzi. U pierwszego z tych filozofów przyjemność została sprowadzona do szczęścia, mającego przede wszystkim wymiar zmysłowy ${ }^{22}$. Drugi podkreśla różnice $\mathrm{w}$ intensyfikacji doznawanych przyjemności oraz $\mathrm{w}$ ich jakości ${ }^{23}$. Dobro i zło w systemie obu myślicieli wynika jednak $\mathrm{z}$ ich skrajnego empiryzmu. Okazuje się bowiem, że jedynie zmysły (zarówno wewnętrzne, jak i zewnętrzne) stanowią ostateczne źródło informacji o tym, czym jest i jakie jest dobro lub zło. „W ramach tak określonej teorii poznania nie rzeczywistość moralna, lecz przyjęty system zmusza do utożsamienia tego, co moralnie dobre, z tym, co daje przyjemność. Bowiem pośród

17 J. Szacki, Historia myśli socjologicznej, t. 1, PWN, Warszawa 1983, s. 279.

18 Zob. V. J. Bourke, Historia etyki, przeł. A. Białek, Wydawnictwo Krupski i S-ka, Warszawa 1994, s. 190-191.

19 Zob. K. von Beyme, Wspótczesne teorie polityczne, przeł. J. Łoziński, Wydawnictwo Naukowe Scholar, Warszawa 2005, s. 121.

20 Zob. J. Szacki, Historia myśli socjologicznej, s. 415.

${ }^{21}$ Zob. K. Gide, K. Rist, Historia doktryn ekonomicznych od fizjokratów do czasów najnowszych, przeł. M. Kwiatkowski, t. 2, Kraków [dokument elektroniczny], s. 92-93.

22 Zob.: J. Bentham, Wprowadzenie do zasad moralności i prawodawstwa, przeł. B. Nawroczyński, PWN, Warszawa 1958; H. Maślińska, Bentham i jego system etyczny, KiW, Warszawa 1964.

${ }_{23}$ Zob. J. S. Mill, Utylitaryzm; T. Kotarbiński, Utylitaryzm w etyce Milla i Spencera, Nakł. Akademii Umiejętności, Kraków 1915. 
wszystkich dóbr jedynie przyjemność jest dobrem ujmowalnym zmysłowo" 24 . W efekcie miarą tego, co „dobre” bądź „lepsze”, stają się osobiste odczucia jednostki. Działający podmiot sam przeto będzie rozeznawał dobro od zła w zależności od intensyfikowania się w nim doznanych przyjemności. A jednak znana jest maksyma Milla sugerująca, że „wolałby być niezadowolonym Sokratesem aniżeli zadowoloną świnią". Taka postawa zadaje kłam wcześniej postawionym założeniom utylitarnym, gdyż sugeruje, że człowiek może wybrać postępowanie wbrew pojawiającemu się w nim pożądaniu jakichś przyjemności, pragnąc osiągnąć jakieś dobra np. intelektualne lub moralne. $\mathrm{W}$ tym momencie pojawia się poważny i głęboki dysonans w utylitaryzmie.

Zresztą ujawniona skaza może być o wiele lepiej rozpoznawalna, gdy umieści się ją na tle szerszej teorii etycznej. Otóż, utylitaryzm jest odmianą ogólnego nurtu etycznego, zwanego eudajmonizmem, według którego czyn byłby moralnie dobry wtedy, gdy uszczęśliwiałby swego sprawcę $e^{25}$. Z pozoru stanowisko to wydaje się niezwykle zachęcające. Przecież gdyby zapytać się ludzi, to każdy chciałby w jakiś sposób być szczęśliwym. W efekcie jawi się bardzo prosta zasada: chcesz postępować moralnie - bądź szczęśliwym. A jednak pojawia się tu pewne wahanie: przecież szczęście niejedno ma oblicze; każdy ma jakieś swoje osobiste, indywidualne i po wielokroć inne poczucie szczęścia. Jak więc wskazać na tej podstawie jedna, uniwersalną drogę działania? Pojawia się jednak tutaj jeszcze trudniejsza refleksja. Może się zdarzyć, że czyjeś szczęście pokryje się z takim samym u innego człowieka. A jeśli będzie ono dotyczyło czegoś rzadkiego, wyjątkowego, jedynego, a nadto niepodzielnego - co wtedy uczynić? Podział takiej wyjątkowej rzeczy nie może być brany pod uwagę, gdyż daną jednostkę uszczęśliwi jedynie całość, a nie tylko jej część. W efekcie takie „szczęście” prowadzi do konfliktu, w wyniku którego wygrywa silniejszy. Skrótowo mówiąc, okazuje się, że taka koncepcja szczęścia sprzyja powszechnemu stosowaniu „prawa dżungli", wedle którego szczęśliwym jest ten, kto jest silniejszy.

24 T. Styczeń, Zarys etyki, cz. 1: Metaetyka, Zakład Małej Poligrafii KUL, Lublin 1974, s. 67.

25 Temat eudajmonizmu podejmowali m.in.: F. W. Bednarski, L'expérience dans l'éthique eudémoniste, Studia Universitatis S. Thome in Urbe, Roma 1979; T. Biesaga, Spór o normę moralności, Wydawnictwo Naukowe PAT, Kraków 1998; M.A. Krąpiec, Decyzja bytem moralnym, „Roczniki Filozoficzne” 1983, t. 31, z. 2, s. 47-65; Was braucht der Mensch um glücklich zu sein, hrsg. K. M. Meyer-Abich, D. Birnbacher, Beck, München 1979; S. Olejnik, Eudajmonizm. Studium nad podstawami etyki, Towarzystwo Naukowe KUL, Lublin 1958; T. Styczeń, Spór z eudajmonizmem czy o eudajmonizm w etyce, "Roczniki Filozoficzne” 1983, z. 2 (31), s. 67-76; T. Ślipko, Zarys etyki ogólnej, WAM, Kraków 1974, s. 67-112; K. Wojtyła, Wykłady lubelskie, red. T. Styczeń et. al., Towarzystwo Naukowe Katolickiego Uniwersytetu Lubelskiego Jana Pawła II, Lublin 2006, s. 207-290. 
Powszechne stosowanie takiej zasady nie sprzyja jednak ani uniwersalnej moralności, ani dobru każdej osoby - a przecież to są fundamentalne założenia etyki.

Okazuje się, że homo oeconomicus doskonale wpisuje się w takie tendencje działania. Ten typ człowieka uwyraźnia się bowiem w postaci wolnej i rozumnej zarazem jednostki, ściśle skoncentrowanej na własnym interesie i przyczyniającej się do swoiście pojmowanego dobra ogólnego. To wspólne dobro wynika ze wspomnianego już utylitaryzmu, w myśl którego najwyższym dobrem jest pożytek jednostki lub społeczeństwa, w postaci „największego szczęścia realizowanego dla największej liczby ludzi". W tej koncepcji antropologicznej dobro pojmowane jest jako prawo wyboru jak największej korzyści, osiąganej jak najmniejszym kosztem. Stąd też każdorazowy wybór działania poprzedza chłodna kalkulacja nad poziomem uzyskiwanego zadowolenia. Wszystko przybiera postać rynkowej kalkulacji, w której rachunek poniesionych kosztów musi być mniejszy od hedonistycznych zysków.

Wskazując więc na główne cechy homo oeconomicus, które charakteryzują jego moralne działania, należy zwrócić uwagę na jego chciwość, indywidualizm i racjonalizm. Nadrzędną zasadą jednak staje się dobrze rozpoznawalny egoizm, rozumianym jako dbałość o własne dobro (czyli szczęście), które to przedkłada się nad dobro i interes innych ${ }^{26}$. Taki człowiek jest motywowany do działania jakimś wewnętrznym popędem, nakierowanym na potrzebę wymiany, czyli tworzenia wolnego rynku. Popęd ten wynika wyłącznie z jego indywidualnych potrzeb, których realizacja ma przynieść pożądane dla niego korzyści. Ponadto trzeba zauważyć, że działania takie są wytyczone według tajemniczego mechanizmu objawiającego się $\mathrm{w}$ zasadzie niewidzialnej ręki rynku ${ }^{27}$. Jest to zbiór nieokreślonych sił działających na rynku, wymuszających od gospodarujących podmiotów konkretne zachowania i postępowanie. Siły te zapewniają samoczynny rozwój gospodarczy, ale równocześnie koordynują zachowania ludzi, wpływają na ich decyzje i działania gospodarcze. Te same więc siły wprawiają $w$ ruch cały potencjał twórczej wymiany gospodarujących ludzi.

Ostatecznie więc w perspektywie takich tendencji egoizm staje się o dziwo - gwarantem rozwoju człowieka, najbardziej pożądana cechą jego zachowania, dzięki której doskonali zarówno siebie, jak i świat,

26 Zob. Encyklopedia PWN, http://encyklopedia.pwn.pl/haslo/3896724/egoizm. html (dostęp: 11.03.2013).

27 "Człowiek [...] myśli tylko o swym własnym zarobku, a jednak w tym, jak i w wielu innych przypadkach, jakaś niewidzialna ręka kieruje nim tak, aby zdążał do celu, którego wcale nie zamierzał osiągnąć". A. Smith, Badania nad natura i przyczynami bogactwa narodów, przekł. księgi 4 A. Prejbisz, księgi 5 B. Jasińska, t. 2, PWN, Warszawa 1954, s. 46-47. 
który wokół siebie tworzy. W zdumiewający sposób okazuje się, że zaspokajając własne potrzeby, czyli uszczęśliwiając siebie, tworzę wokół siebie aurę swoistego nieba, do którego jednak tylko ja sam mam dostęp - inni o tyle, o ile przyczynią się do uprzyjemnienia mojego w nim pobytu. Zasada utylitarna jest przy tym rozumiana bardzo specyficznie. Oto okazuje się - jak napisał o tym Smith - że w działaniach rynkowych poszczególne jednostki, opierając się na swojej racjonalności, dobierają optymalne środki w celu maksymalizowania własnych korzyści. Dlatego też człowiek taki zdobywa odpowiednią wiedzę, aby nakłonić drugiego do dogodnego dla siebie kontraktu. Odwołuje się wtedy do egoizmu drugiej osoby, albowiem jemu także przyświeca podobny cel. Dobro ogółu, które ma być zrealizowane w myśl zasady utylitarnej, objawia się w szczęściu zaspokajania własnych potrzeb ekonomicznych, zestrojonych regułami gry wolnorynkowej i przynoszących obopólny zysk wynikły z ogólnego zestrojenia ze sobą poszczególnych indywidualnych egoizmów.

Rzeczywistość zdaje się potwierdzać sensowność takich praktyk gospodarczych, leżących u podstaw etyki eudajmonistycznej, a jednak pojawia się pewien szczegół, który w ogólnej koncepcji łatwo przeoczyć. Otóż, w utylitaryzmie w centrum zainteresowania zawsze leży jakaś „większość". Społeczeństwo obejmuje swym zasięgiem także niewspomnianą dotychczas „mniejszość”, a więc tę grupę ludzi, która z jakichś względów nie chce wziąć udziału w rynkowych rozgrywkach, nie partycypuje w ugranym zysku lub po prostu żywi zgoła całkiem inne upodobania co do ogólnie przyjętego modelu „powszechnego szczęścia”.

Okazuje się, że właśnie owa „mniejszość” stanowi fundamentalną siłę krytyczną całego eudajmonizmu. W utylitaryzmie uszczęśliwiający pożytek wybieranych działań dotyczy większości osób spośród grupy dokonującej wyboru. Tymczasem mniejszość w efekcie nie korzysta z owego pożytku, a tym samym jest w jakiś sposób nieszczęśliwa. Ostatecznie prowadzi to do paradoksu, gdzie podjęte działanie równocześnie okazuje się uszczęśliwiające i unieszczęśliwiające. Innymi słowy, jeden i ten sam czyn jest i dobry, i zły - w zależności kto i jak go doznaje czy odczuwa. Taki czyn jest sprzeczny w sobie, a sprzeczność nie ma racji bytu ${ }^{28}$, po prostu nie może zaistnieć. W konsekwencji trzeba wyraźnie zaznaczyć, że sprzeczność jest immanentnie zapodmiotowiona w całym nurcie eudajmonistycznym, a w tym kontekście także w utylitaryzmie. Ostatecznie homo oeconomicus, który wyrasta z tej koncepcji, jawi się jako

28 Zob. M.A. Krąiec, Metafizyka. Zarys teorii bytu, Redakcja Wydawnictw KUL, Lublin 1988, s. 144-145. Powołuje się on na myśl Arystotelesa, który twierdził: „Niemożliwe, aby coś zarazem było i nie było". Arystoteles, Metafizyka, przeł. K. Leśniak, PWN, Warszawa 1983, IV, 4. 
jednostka skrajnie zindywidualizowana i zapodmiotowiona w osądach swej moralności we własnym egoizmie.

\section{Homo personalis i jego moralność}

Skłonności egoistyczne homo oeconomicus - jakże przydatne w kontekście pomnażania zysku - przenoszone na grunt etyczny okazują się błędne i wewnętrznie sprzeczne. Aby więc ów teoretyczny twór nabrał realnych wymiarów, koniecznie trzeba zracjonalizować go przez odniesienie do osobowego bytu człowieka.

Kim jest homo personalis? To osobowy byt substancjalny, istniejący realnie, samoistnie, a zarazem wewnętrznie spójnie. Jest konkretnym, jednostkowym bytem, posiadającym swój radykalny indywidualizm. Osoba jest jednostką posiadającą rozumną naturę, dzięki której może poznawać prawdę, myśleć twórczo, rozeznawać dobro i zło, a także autonomicznie i kreatywnie działać. Można rzec, że „osoba jest [...] samoistnym podmiotem istnienia i działania" ${ }^{29}$, ma więc swoistą podmiotowość ontyczną. W tym kontekście w pełni objawia się Boecjuszowa definicja osoby pojmowanej jako „indywidualna substancja rozumnej natury" ${ }^{\prime 30}$. Wpatrując się jednak coraz głębiej w jej istotę, można dostrzec jej swoistą podmiotowość egzystencjalną. Wyraża się to w odróżnieniu bytu osobowego, ujmowanego jako ktoś od wszelkiego innego bytu przedmiotowego ujmowanego jako coś. „Człowiek jest przedmiotowo »kimś« - i to go wyodrębnia wśród reszty bytów widzialnego świata, które przedmiotowo są zawsze tylko »czymś«. To proste, elementarne rozróżnienie kryje w sobie głęboką przepaść, jaka dzieli świat osób od świata rzeczy"31.

Człowiek jako osoba jest podmiotem działającym w sposób wolny i świadomy. Objawia się to $\mathrm{w}$ indywidualnym doświadczeniu „bycia człowiekiem". Dzieje się to na co dzień, w różnorakich czynnościach ludzkiego działania. Każdy jest podmiotem swych czynów: sam je obmyśla, realizuje i snuje nad nimi refleksję. Doświadczenie samego siebie jest tym donioślejsze, że nie potrzeba w nim żadnych dodatkowych narzędzi, znaków językowych ani też dowodów czy rozumowań. Każdy

29 K. Wojtyła, Personalizm tomistyczny, w: idem, Aby Chrystus się nami postugiwat, przygot. J. Hennelowa, Znak, Kraków 1979, s. 432.

${ }_{30}$ Zob. A.M. Boecjusz, Przeciwko Eutychesowi i Nestorjuszowi, w: idem, Traktaty teologiczne, przeł. R. Bielak, A. Kijewska, Wydawnictwo Antyk, Kęty 2001, s. 70.

${ }_{31}$ K. Wojtyła, Miłość i odpowiedzialność, red. T. Styczeń et al., TN KUL, Lublin 1986, s. 24. 
bowiem sam, i to w sposób bezpośredni, odbiera bezsporne fakty, które są bezpośrednio „własne”, czyli „ludzkie” ${ }^{\prime 32}$.

W akcie ludzkiego działania objawia się doświadczenie własnego Ja. W ten sposób bez żadnych pośredników człowiek styka się zarówno ze swoim Ja, ale też z tym wszystkim, co jest "moje”, co należy do mnie samego. Te dwa wymiary wzajemnie się warunkują i przenikają. Oto „moje” są czynności poznawcze, wolitywne czy emocjonalne, zatem to ja sam poznaję, chcę bądź kocham. Owo Ja jest obecne we wszystkich moich aktach ${ }^{33}$.

Koniecznie trzeba także zwrócić uwagę na to, że człowiek tworzy konkretne i ścisłe nieraz relacje $\mathrm{z}$ bytem innym aniżeli własne Ja. W ten sposób tworzy się relacja Ja-Ty, która uświadamia każdemu człowiekowi, że oprócz jego indywidualności istnieją w świecie także inne podmioty jednostkowe, z którymi można wejść w konstruktywny dialog ${ }^{34}$. Afirmacja takiej „,inności” dokonuje się więc przez przekroczenie granicy świadomości własnej egzystencji i poszanowania odmienności i różnorodności innych bytów osobowych. Ludzka egzystencja urzeczywistnia się przez „bycie-we-wspólnocie”, staje się to faktycznym spotkaniem i wzajemną afirmacją wszystkich konstytuujących ową wspólnotę osób. Ta wspólnota staje się więc rzeczywistością sui generis, tworząc swoiście pojmowany żywy organizm ${ }^{35}$.

Jak wynika z wcześniejszych ustaleń, relacje międzyosobowe tworzą swoiście personalistyczny klimat wspólnej więzi. Wzajemne odniesienie zakłada obopólną równość ontologiczną jak również wzajemną afirmację. Ich podstawą jest bowiem wspólne dobro każdego człowieka. W ten sposób rodzą się główne zasady życia społeczno-gospodarczego, które normują w sposób etyczny działalność gospodarczą, a zarazem wyrastają z personalistycznej koncepcji człowieka jawiącego się jako byt osobowy.

1. Pierwsza zasada to dobro wspólne. Okazuje się bowiem, że ludzka jednostka - ze względu na przymioty własnej natury - najlepiej

32 Zob. A. Siemianowski, Antropologia filozoficzna, Gaudentinum, Gniezno 1996, s. $105-117$.

33 Można wysunąć tezę, że właśnie owo Ja i jego świadomość, jak i wewnętrzna "doświadczalność" przez daną jednostkę, świadczy o normalności danego podmiotu. Ewentualny defekt lub błąd w poprawnym odbiorze własnego Ja dowodziłby stanu nie-normalnego, chorobowego.

34 Zob. M. Buber, Ich und Du, w: idem, Das dialogische Prinzip, Lambert, Heidelberg 1965 , s. 8 .

35 Obraz ten znany jest już od starożytności u Arystotelesa, św. Pawła, a w późniejszym czasie u św. Tomasza z Akwinu. Współcześnie powołuje się na niego wielu personalistów. Zob. J. Majka, Filozofia społeczna, Wydawnictwo Wrocławskiej Księgarni Archidiecezjalnej, Wrocław 1982, s. 352 i n. 
realizuje swą osobowość w społeczeństwie ${ }^{36}$. Dlatego też dobro wspólne jawi się jako kwestia wspólnych dążeń wielu ludzi. Ich przedmiotem są wartości czy też dobra zewnętrzne, jak również te, które dotykają wnętrza bytu osobowego. Stąd ten rodzaj dobra należy pojmować jako wartość społecznomoralną, dzięki której będą mogły zaistnieć warunki dla integralnego rozwoju pełni człowieka $^{37}$.

2. Zasada pomocniczości tłumaczy, że nadrzędne społeczności nie powinny odbierać pomniejszym jednostkom ich kompetencji i możliwości działania, jednakże - gdy owe mniejsze grupy nie potrafią sprostać wyzwaniom - w imię wspólnego dobra należy im się pomoc udzielona przez społeczności wyższego rzędu. Szczególnym przykładem jej realizacji są relacje, jakie zachodzą między podmiotami gospodarczymi a państwem lub olbrzymimi korporacjami a mniejszymi firmami. Istniejąca w tej mierze słuszna autonomia nie może jednak prowadzić do działań egoistycznych, które godziłyby w realizacje wspólnego dobra, a więc w dobro osobowe.

3. Zasada solidarności pojawia się chociażby w kontekście wspólnego działania „przeciwko degradacji człowieka jako podmiotu pracy, połączonej z niesłychanym wyzyskiem $\mathrm{w}$ dziedzinie zarobków, warunków pracy i troski o osobę pracownika" ${ }^{38}$. Chodzi tu o powzięcie odpowiedzialności nie tylko za własne postępowanie, ale także za drugiego człowieka. Wprowadza ona swoisty ład i porządek humanistyczny, a dzięki temu podkreśla personalistyczny wymiar życia społeczno-gospodarczego.

Przytoczone zasady życia społeczno-gospodarczego wywodzą się wprost z założeń ontologicznych wizji homo personalis. Opierając się na fundamentalnych jego kategoriach, normują jego działania w przestrzeni relacji z innymi osobami, jak też we wspólnej z nimi aktywności ekonomicznej. Należy przy tym zauważyć, że wymiar etyczny wywodzi się $\mathrm{w}$ tym przypadku nie $\mathrm{z}$ kategorii szczęścia - jak miało to miejsce w kontekście homo oeconomicus - lecz z istoty struktury bytowej osoby ludzkiej. Etyczna zasada przyjmie ostatecznie wersję powinnościorodnego czynu afirmacji każdej osoby, ze względu na jej godnośćc ${ }^{39}$. Stąd fundamentem

36 Zob. S. Kowalczyk, Człowiek a społeczność. Zarys filozofii społecznej, RW KUL, Lublin 1996, s. 118 i n.

37 Więcej na ten temat zob.: J. Messner, Das Gemeinwohl, A. Fromm, Osnabrück 1962; J. Krucina, Dobro wspólne. Teoria i jej zastosowanie, Wydawnictwo Wrocławskiej Księgarni Archidiecezjalnej, Wrocław 1972; J. Kondziela, Normatywny charakter "Bonum commune", "Śląskie Studia Historyczno-Teologiczne” 1970, nr 2, s. 51-81; J. Krucina, Dobro osobowe a dobro wspólne, „Ateneum Kapłańskie” 1970, nr 74, s. 218-231.

38 Jan Paweł II, Laborem exercens, "Znak” 1982, nr 8 (332/334).

39 Zob. T. Styczeń, J. Merecki, ABC etyki, RW KUL, Lublin 1983, s. 27. 
podejmowanych działań powinna każdorazowo być istota bytu osobowego w postaci jej wrodzonej i niezbywalnej godności. To zaś oznacza, że człowiek stanowi dobro najwyższej jakości, godne szacunku ze względu na nie samo, na jego własną wewnętrzną dostojność i wielkość. W ten sposób osoba staje się wartością moralną samą w sobie ${ }^{40}$.

Przyznanie człowiekowi osobowej wartości moralnej, o wyraźnie zarysowanej moralnej konstytucji, pociąga za sobą ważną konsekwencję przy określaniu jego stosunku do podejmowanej przez niego rozumnej działalności. Człowiek jako osoba wkracza w różnorodne dziedziny swego życia, nie tylko jako ich twórca i aktywny uczestnik, ale także jako ich rzeczywiste centrum i ostateczny punkt odniesienia. Jeżeli bowiem człowiek, z racji swego osobowego charakteru, jest wartością moralną, nadrzędną w stosunku do wszystkich rzeczy i dóbr, wobec tego musi to znaleźć swój wyraz i przedłużenie w świadomie przez niego podejmowanych działaniach. Dotykają one nie tylko świata zewnętrznego, lecz także przemieniają samego człowieka. Nakierowanie na dobro i rozwój osobowy stanowi zasadę powszechną, odnoszącą się do wszystkich realizowanych przez człowieka aktów rozumnych. Dlatego też będą one o tyle prawdziwie ludzkie i prawidłowe, o ile będą się zbiegać i scalać w doskonałość osoby ludzkiej. Ów dynamiczny aspekt osobowości, tkwiąca niejako w jej strukturze presja w kierunku przekraczania samej siebie i zmierzania do coraz to wyższych wartości, stanowi samą istotę nakazu moralnego, jaki przeżywa każdy człowiek o zdrowej strukturze osobowościowej. Brak tego nakazu jawi się jako jego ograniczenie lub zachwianie.

\section{Zakończenie}

Wolny rynek stanowi dziś najbardziej rozpowszechnioną formę działalności gospodarczej. Skutkuje to jednak ogromnym zmaterializowaniem wszystkich wartości - nie tylko tych, które bezpośrednio związane są z działalnością rynkowa, lecz również i tych, które w ogólnym sensie pojawiają się w ludzkim życiu. Taki stan rzeczy prowadzi do zanegowania duchowego aspektu życia człowieka, a jego wolność zostaje zaprzęgnięta do świadczenia usług ekonomicznych. Człowiek ostatecznie zaczyna jawić się jako element rzeczywistości gospodarczej, sprowadza się więc go do swoistego trybu działającego w maszynce do zarabiania pieniędzy. Ecce homo oeconomicus - człowiek racjonalny, którego cała energia twórcza nastawiona jest wyłącznie na realizację ekonomicznych wartości. Taka antropologia wymusza niejako swoistą etykę, nastawioną z grubsza na egoistyczne szczęście jednostki za wszelką cenę zmierza-

40 Zob. T. Ślipko, Zarys etyki szczegótowej, t. 2, WAM, Kraków 1981, s. 110. 
jącej do zysku. Ostatecznie jednak dochodzi tu do zanegowania fundamentalnej kategorii etycznej, jaką jest dobro i to dobro człowieka pojmowanego jako ludzka osoba.

$\mathrm{Z}$ tego też względu konieczne jest, aby przeciwstawić się wizji homo oeconomicus i wskazać na homo personalis, na człowieka będącego bytem osobowym. W tym kontekście jego istota będzie warunkowała jakość podejmowanej ludzkiej aktywności. Podejmując się działalności rynkowej, realizuje on charakterystyczne dla niej zadania, lecz nie ze względu na sam fakt pomnażania zysków. Przeciwnie, wszelka działalność ekonomiczna musi być podporządkowana głównemu celowi, którym jest sam człowiek. Z perspektywy personalistycznego spojrzenia na taką aktywność ludzką chodzi o integralny rozwój samego człowieka, budowany także przez jego animacje gospodarcze.

W ten sposób łączy się subiektywne oczekiwania ekonomiczne z obiektywnymi wartościami moralnymi, na czele których stoi fundamentalna wartość ludzkiej godności. Tworzony porządek ekonomiczny posiada więc ze swej istoty ludzki charakter - czerpie korzyści z aktywności rynkowej, a zarazem nie redukuje osoby ludzkiej do przedmiotowego elementu ekonomii. Pełna afirmacja godności osoby ludzkiej umożliwi głębokie uczestnictwo w życiu społecznym, a zarazem wypracowanie potrzebnych człowiekowi w egzystencji dóbr materialnych. Homo personalis stoi $\mathrm{w}$ ten sposób u podstaw moralnego personalizmu ekonomicznego.

\section{Streszczenie}

\section{Homo oeconomicus versus homo personalis. Człowiek pomiędzy ekonomiq a etyką}

\section{Słowa kluczowe}

Człowiek; osoba; ekonomia; etyka

Pytanie o to, kim jest człowiek, towarzyszy ludzkości niemal od samego jej początku. Odpowiedź na to pytanie kształtowała się przez wieki. Zrozumienie „faktu bycia człowiekiem” ma ogromne znaczenie nie tylko dla niego samego, ale także dla całej ludzkości. Koncepcja człowieka leży u podstaw rozumienia społeczeństwa, polityki, gospodarki, religii, kultury, a nawet całej cywilizacji.

We współczesnym społeczeństwie istotną rolę odgrywa ekonomia - nie tylko jako nauka, ale także jako sposób na życie. Wykreowała ona specyficzną wizję człowieka - homo oeconomicus. Jest to najczęściej hipotetyczny twór jednostkowy. Działa on racjonalnie, dokonuje wyborów wyłącznie według kryteriów ekono- 
micznych. Jego naczelną wartościa, którą kieruje się w swym życiu, jest zysk ekonomiczny. W takiej postawie często niknie wymiar moralny jego działania.

Żeby nie dopuścić do demoralizacji takiego człowieka, konieczne jest odniesienie się do etyki. W tej perspektywie człowiek jest również bytem racjonalnym, posiadającym wolną wolę, ale zarazem odpowiadającym za swe postępowanie. W nurcie eudajmonistycznym podkreśla się jego indywidualizm, w deontonomizmie - prawne i społeczne uzależnienie. Jednak wydaje się, że najpełniejsza wizja człowieka pokazuje się w personalizmie, w którym człowiek objawia się jako osoba. Dlatego też alternatywą dla współczesnych dylematów moralnych w ekonomii jest etyka oparta na godności osoby ludzkiej.

\section{Summary}

\section{Homo oeconomicus versus homo personalis. A man between economics and ethics}

\section{Keywords}

Man; person; economic; ethics

The question "Who is the man?" accompanied mankind almost from the very beginning. The answer to this question developed over the centuries. Understanding "the fact of being a man" is of great importance not only for himself but also for all mankind. The concept of man is the basis of human understanding of society, politics, economy, religion, culture, and even the whole civilization.

In today's society, economics plays an important role - not only as a science, but also as a way of life. It created a specific vision of man - homo economicus. It is most often hypothetical imaginary creature. It works reasonably and makes choices based on economic criteria. The main value - determining its actions - is economic profit. In this attitude moral dimension of his actions often disappears.

To prevent the demoralization of such a man, it is necessary to refer to ethics. In this perspective, the man is a rational being also, having free will, but at the same time, responsible for their actions. In eudaimonism - the individualism is emphasized. In deontonomism - social and legal dependence. However, it seems that the most complete vision of man is showed in personalism, in which a man reveals himself as a person. Therefore, ethics based on the human dignity is an alternative to contemporary moral dilemmas in economics.

\section{Bibliografia}

Arystoteles, Metafizyka, przeł. K. Leśniak, PWN, Warszawa 1983.

Arystoteles, Polityka, przeł. i oprac. L. Piotrowicz, Zakład im. Ossolińskich, Wrocław 1953. 
Baszkiewicz J., Powszechna historia ustrojów państwowych, Arche, Gdańsk 1998.

Bauman Z., Socjologia, przeł. J. Łoziński, Zysk i S-ka, Toruń 1996.

Bednarski F.W., L'expérience dans l'éthique eudémoniste, Studia Universitatis S. Thome in Urbe, Roma 1979.

Bentham J., Wprowadzenie do zasad moralności i prawodawstwa, przeł. B. Nawroczyński, PWN, Warszawa 1958.

Beyme K. von, Wspótczesne teorie polityczne, przeł. J. Łoziński, Wydawnictwo Naukowe Scholar, Warszawa 2005.

Biesaga T., Spór o normę moralności, Wydawnictwo Naukowe PAT, Kraków 1998.

Boecjusz A.M., Przeciwko Eutychesowi i Nestorjuszowi, w: idem, Traktaty teologiczne, przeł. R. Bielak, A. Kijewska, Wydawnictwo Antyk, Kęty 2001.

Boecjusz A.M., Traktaty teologiczne, przeł. R. Bielak, A. Kijewska, Wydawnictwo Antyk, Kęty 2001.

Bourke V.J., Historia etyki, przeł. A. Białek, Wydawnictwo Krupski i S-ka, Toruń 1994.

Buber M., Das dialogische Prinzip, Lambert, Heidelberg 1965.

Buber M., Ich und Du, w: idem, Das dialogische Prinzip, Lambert, Heidelberg 1965.

Encyklopedia PWN, http://encyklopedia.pwn.pl/haslo/3896724/egoizm.html (dostęp: 11.03.2013).

Essays on Economics Society, Collected Works, t. 4, Toronto 1967.

Gide K., Rist K., Historia doktryn ekonomicznych, t. 2, Warszawa [b.r.w.].

Hobbes T., Elementy filozofii, Warszawa 1956.

Hobbes T., Lewiatan, czyli materia, forma i władza państwa kościelnego i świeckiego, przeł. Cz. Znamierowski, PWN, Warszawa 1954.

Izdebski H., Historia myśli politycznej i prawnej, C. H. Beck, Warszawa 2001.

Jan Paweł II, Laborem exercens, "Znak" 1982, nr 332/334.

Kondziela J., Normatywny charakter „Bonum commune”, „Śląskie Studia Historyczno-Teologiczne" 1970, nr 2.

Kotarbiński T., Utylitaryzm w etyce Milla, Nakł. Akademii Umiejętności, Kraków 1915.

Kowalczyk S., Człowiek a społeczność. Zarys filozofii społecznej, RW KUL, Lublin 1996, Lublin 1996.

Krapiec M.A., Metafizyka. Zarys teorii bytu, Redakcja Wydawnictw KUL, Lublin 1988.

Krąpiec M.A., Decyzja bytem moralnym, „Roczniki Filozoficzne” 1983, z. 2 (31).

Krucina J., Dobro osobowe a dobro wspólne, „Ateneum Kapłańskie” 1970, nr 74.

Krucina J., Dobro wspólne. Teoria i jej zastosowanie, Wydawnictwo Wrocławskiej Księgarni Archidiecezjalnej, Wrocław 1972.

Majka J., Filozofia społeczna, Wydawnictwo Wrocławskiej Księgarni Archidiecezjalnej, Wrocław 1982.

Maślińska H., Bentham i jego system etyczny, KiW, Warszawa 1964.

Messner J., Das Gemeinwohl, A. Fromm, Osnabrück 1962. 
Mill J.S., O wolności, przeł. M. Ossowska, A. Kurlandzka, PWN, Warszawa 1959.

Mill J.S., One the Definition of Political Economy and on the Method of Investigation Proper to it, w: Essays on Economics Society, Collected Works, t. 4, Toronto 1967.

Mill J.S., Utylitaryzm. O wolności, przeł. M. Ossowska, A. Kurlandzka, PWN, Warszawa 1959.

Morawski W., Socjologia ekonomiczna. Problemy, teoria, empiria, Wydawnictwo Naukowe PWN, Warszawa 2001.

Olejnik S., Eudajmonizm. Studium nad podstawami etyki, Towarzystwo Naukowe KUL, Lublin 1958.

Ossowski S., Z zagadnień psychologii społecznej, Wydawnictwo Naukowe PWN, Warszawa 2000.

Platon, Państwo, przeł. W. Witwicki, Wydawnictwo Antyk, Kęty 2006.

Siemianowski A., Antropologia filozoficzna, Gaudentinum, Gniezno 1996.

Smith A., Teoria uczuć moralnych, przeł., wstępem i przypisami opatrzyła D. Petsch, PWN, Warszawa 1989.

Styczeń T., ABC etyki, RW KUL, Lublin 1983.

Styczeń T., Spór z eudajmonizmem czy o eudajmonizm w etyce, "Roczniki Filozoficzne" 1983, z. 2 (31).

Styczeń T., Zarys etyki, cz. 1: Metaetyka, Zakład Małej Poligrafii KUL, Lublin 1974.

Szacki J., Historia myśli socjologicznej, t. 1, PWN, Warszawa 1983.

Ślipko T., Zarys etyki ogólnej, WAM, Kraków 1974.

Ślipko T., Zarys etyki szczegółowej, t. 2, WAM, Kraków 1981.

Taylor W.L., Francis Hutcheson and David Hume as Predecessors of Adam Smith, Durham N.C, 1965.

Was braucht der Mensch um glücklich zu sein, hrsg., K. M. Meyer-Abich, D. Birnbacher, Beck, München 1979.

Wojtyła K., Wykłady lubelskie, red. T. Styczeń et. al., Towarzystwo Naukowe Katolickiego Uniwersytetu Lubelskiego Jana Pawła II, Lublin 2006.

Wojtyła K., Aby Chrystus się nami postugiwał, przygot. J. Hennelowa, Znak, Kraków 1979.

Wojtyła K., Miłość i odpowiedzialność, red. T. Styczeń et al., TN KUL, Lublin 1986.

Wojtyła K., Personalizm tomistyczny, w: idem, Aby Chrystus się nami posługiwat, przygot. J. Hennelowa, Znak, Kraków 1979. 